\title{
To the question of the influence of a silanol cover on the protolytic properties of aminopropyl silica gels
}

\author{
O. V. Filisteev ${ }^{\star}$ A. V. Sharov \\ Kurgan State University \\ 63 Sovetskaya st., Kurgan, 640020, Russia \\ *email: filisteev@kgsu.ru
}

\begin{abstract}
The paper proposes a model that describes the acid-base properties of amino groups grafted onto the surface, taking into account their interaction with silanol groups. For this, aminopropyl silica was chosen as an object with well-studied methods of preparation, structure and properties. The isotherms of sorption of hydrogen ions on aminopropyl silica were obtained by potentiometric method. The experimental points were analyzed numerically, taking into account the presence of an electric double layer, the presence of surface processes competing with the sorption of hydrogen ions, and the peculiarities of the behavior of silanol groups when the degree of surface filling with hydrogen ions changes. The resulting model makes it possible to carry out a preliminary calculation of the sorption of hydrogen ions on the surface of aminopropyl silica.
\end{abstract}

Keywords: functionalized sorbents; aminopropyl silica; protolytic properties; curves of potentiometric titration of sorbents

Received: 03.11.2020. Accepted: 09.12.2020. Published:30.12.2020.

(c) Filisteev 0. V., Sharov A. V., 2020

\section{Introduction}

To describe the reactivity of the surface groups of sorbents, many numerical algorithms for the analysis of complexation on the surface are used. They are based on the numerical solution of equations that make it possible to calculate the experimentally determined characteristics of surface equilibria. The equations are usually solved with respect to the values of the equilibrium constants. In addition to them, the roots of the equation can be other parameters of the system (capacity of DES, the proportion of certain groups from the total concentration, etc.). In this case, it is possible to use models that take into account DES (the theory of complexation on the surface, including the Guy-Chapman and Stern models, the CD-MUSIC model
[1-5], and those operating without taking into account DES (models of chemical reactions, distribution of groups by equilibrium constants [6-9]).

Common materials, most often obtained by surface modification, are sorbents containing basic nitrogen $[10,11]$. Nitrogencontaining groups often interact with acidic groups on the surface, which makes it difficult to quantitatively analyze their acid-base and complexing properties. In such cases, the equilibrium constants with the participation of nitrogen-containing groups are conditional with respect to the content of interfering groups. A typical example is the acid-base and complexing properties on the surface of various types of aminosilicas. The presence of acidic silanol groups 
leads to the fact that the experimentally determined constants are significantly lower than the tabulated ones for structures similar to those present on the surface. The processes of interaction of surface groups with each other lead to different interpretations of the initial data, depending on the model used: the presence of several types of nitrogen-containing groups, different in the energy of sorption interaction with ions in solution, the presence of interactions of nitrogen-containing groups with each other, etc. $[6,8,11-13]$. At the same time, a model of the interaction of basic nitrogen-containing groups with acidic ones on the surface has not yet been constructed.
The available models require the involvement of a significant amount of preliminary obtained experimental data [14]. The presence of such a model would allow a preliminary calculation of the sorption properties of materials with the properties described above.

In this work, we propose a variant of describing the interactions of amino groups and silanol groups on the surface of aminopropyl silica gels during the adsorption of hydrogen ions from a solution. The model takes into account the effect of the diffusion double layer, as well as the direct chemical interaction of amino and silanol groups.

\section{Experimental}

Aminopropyl silicas were chosen as test objects as materials with well-studied methods of synthesis, surface structure, and acid-base properties [8]. For the synthesis of aminopropyl silicas, industrial silica gels KSKG and KSMG were used. Silica gels were preliminarily crushed and divided into fractions by sieving (used fraction $0.25-0.5 \mathrm{~mm}$ ). The particles were separated from the dust by repeated washing in distilled water. Before inoculation, the silica gels were heated at a temperature of $150{ }^{\circ} \mathrm{C}$ to constant weight. The grafting of aminopropyl groups was carried out by impregnation of silica gels in solutions of 3-aminopropyltriethoxysilane (Acros Organics) in anhydrous toluene [15]. To obtain samples with different surface concentration of amino groups, different temperatures and contact times were used. The impregnation time was varied from $20 \mathrm{~min}$ to 24 hours, the temperature from room temperature to $60^{\circ} \mathrm{C}$.

The moisture content of the samples was determined by heating at $150{ }^{\circ} \mathrm{C}$ to constant weight using an automatic
Sartorius analyzer. The specific surface area was determined by the multipoint BET method from nitrogen sorption isotherms at $-196^{\circ} \mathrm{C}$ on a SORBI MS analyzer. The surface concentration of aminopropyl groups was determined by the Kjeldahl method.

The curves of potentiometric titration of the samples were recorded using the method of one sample as follows. A weighed sample with a known moisture content of about $0.3 \mathrm{~g}$, weighed on an analytical balance, was mixed with $30 \mathrm{ml}$ of a $0.1 \mathrm{M}$ potassium chloride solution. The cell with the suspension was placed in a thermostat with a temperature of $25{ }^{\circ} \mathrm{C}$. Titration was carried out with $0.0500 \mathrm{M}$ hydrochloric acid solution (fixanal). The indicator system was a glass electrode and a silver chloride reference electrode. The measurement of $\mathrm{pH}$ up to 3 decimal places was carried out on an "Expert 001 " ionomer. The time to reach equilibrium after adding each portion of the titrant is not less than 15 minutes. Equilibrium at each point was considered 
to be achieved if the $\mathrm{pH}$ did not change within 5 min by more than 0.002 units.

\section{Processing of experimental curves}

The obtained experimental points were transformed into the dependence of the surface charge on $\mathrm{pH}$. The surface charge was calculated using Eq. (1).

$$
\sigma_{\mathrm{e}}=\frac{F\left(C_{\mathrm{H}^{+}}-\left[\mathrm{H}^{+}\right]\right)}{S C_{\mathrm{k}}}
$$

Here $\sigma_{e}$ is the surface charge calculated from the experimental data, $\mathrm{C} / \mathrm{m}^{2} ; \mathrm{C}_{\mathrm{H}^{+}}-$ total concentration of hydrochloric acid in solution, mol/l; $\left[\mathrm{H}^{+}\right]$- concentration of hydrogen ions in solution, $\mathrm{mol} / \mathrm{l} ; \mathrm{S}$ specific surface area, $\mathrm{m}^{2} / \mathrm{g} ; C_{\mathrm{k}}-$ concentration of silica suspension, $\mathrm{g} / \mathrm{l}$.

The concentration of hydrogen ions in the solution was calculated from the $\mathrm{pH}$ values, taking into account the activity coefficients of hydrogen ions in the solution.

When analyzing the experimental points, the following surface chemical processes were taken into account.

$$
\begin{aligned}
& -\mathrm{NH}_{2 \mathrm{~s}}+\mathrm{H}_{\mathrm{s}}^{+}=-\mathrm{NH}_{3}{ }^{+} \mathrm{s} \\
& \equiv \mathrm{SiOH}_{\mathrm{s}}=\equiv \mathrm{SiO}^{-}{ }_{\mathrm{s}}+\mathrm{H}^{+}{ }_{\mathrm{s}}
\end{aligned}
$$

The ' $s$ ' index indicates that the particles belong to the surface layer.

From the charge balance condition, it follows that the surface charge $\sigma$, calculated from the concentration of particles determining the charge, can be expressed by Eq. (4):

$$
\sigma=\frac{F}{S C_{k}}\left(\left[-\mathrm{NH}_{3 \mathrm{~s}}^{+}\right]-\left[\equiv \mathrm{SiO}_{\mathrm{s}}^{-}\right]\right)
$$

Equilibrium concentrations of ammonium groups and deprotonated silanols were calculated based on the material balance conditions:

$$
C_{-\mathrm{NH}_{2} \mathrm{~s}}=\left[-\mathrm{NH}_{2 \mathrm{~s}}\right]+\left[-\mathrm{NH}_{3 \mathrm{~s}}^{+}\right]
$$

$$
C_{\equiv \mathrm{SiOHs}}=\left[\equiv \mathrm{SiOH}_{\mathrm{s}}\right]+\left[\equiv \mathrm{SiO}_{\mathrm{s}}^{-}\right]
$$

where $C_{-\mathrm{NH}_{2} \mathrm{~s}}$ and $C_{\equiv \mathrm{SiOHs}}$ are the total concentration of surface amino groups and silanol groups, respectively.

Taking into account Eqs. (5) and (6), expression (4) takes the form:

$$
\sigma=\frac{F}{S C_{\mathrm{k}}}\left(\frac{C_{-\mathrm{NH}_{2} \mathrm{~s}}}{1+\frac{1}{K\left[\mathrm{H}_{\mathrm{s}}^{+}\right]}}-\frac{C_{\equiv \mathrm{SiOHs}}}{1+\frac{\left[\mathrm{H}_{\mathrm{s}}^{+}\right]}{K_{\mathrm{s}}}}\right)
$$

In Eq. (7), $K$ and $K_{s}$ are the equilibrium constants of Eq. (2) and (3), respectively. The transition from the concentration of hydrogen ions in the surface layer to the concentration in the bulk of the solution was carried out using the well-known equation:

$$
\left[\mathrm{H}_{\mathrm{s}}^{+}\right]=\left[\mathrm{H}^{+}\right] e^{-\frac{F \psi_{0}}{R T}},
$$

where $\psi_{0}$ is the potential in the zero plane relative to the solution volume. It was determined through the equation of the diffuse DES model:

$$
\sigma=-0.1174 \sqrt{I} \sinh \frac{F \psi}{2 R T},
$$

where $\psi$ is the potential of the beginning of the diffuse layer, which is taken to be equal to the potential $\psi_{0}$ [16].

Eqs. (8) and (9) were substituted into (7), yielding the simplified expression:

$$
s_{0}=\sqrt{\frac{\sum_{i=1}^{n}\left(\sigma_{\mathrm{e} i}-\sigma_{i}\right)^{2}}{n}}
$$

In Eq. (10), $\sigma_{\mathrm{e} i}$ and $\sigma_{i}$ are the surface charges calculated by using Eq. (1) and (7), respectively, and $n$ is the number of experimental points. Numerical minimization was performed using the built-in tools 
of Mathematica 10 software package. The chosen parameter for minimization in all cases was the constant $K$. The acidity constant of silanol groups, 7.67, was taken from [14]. The total concentration of silanol groups, $C_{\equiv \mathrm{SiOHs}}$, participating in the process is difficult to determine experimentally. Therefore, this value was also an adjustable parameter during minimization. The evaluation of the results of minimization was also carried out according to the value of $s_{0}$.

\section{Results and discussion}

When choosing $K$ and $C_{\equiv \text { SiOHs }}$ by minimizing Eq. (7), the following results were obtained. The $\log K$ grows to the values in the range of 9.9-10.32 in comparison with conditional constants determined without taking into account the influence of silanol groups. In this case, the $s_{0}$ distribution over the values of the surface concentration is observed, shown in Fig. 1a.

The shape of the points indicates an increase in the deviation of the calculated from the experimental points with an increase in the surface concentration (not a random nature of the distribution of $s_{0}$ on the $\mathrm{C}_{-\mathrm{NH}_{2} \mathrm{~s}}$ scale). Fig. $1 \mathrm{~b}$ shows examples of approximation of experimental points of charge versus $\mathrm{pH}$ dependence. For low concentrations of grafted groups, the deviation is not very significant. It is seen that the greatest deviation at high concentra- tions of amino groups is observed at low degrees of surface coverage with hydrogen ions. Thus, Eq. (7) is not suitable for fitting the points of titration curves.

The non-random nature of the distribution of points in Fig. 1a speaks of a regularity that we did not take into account when calculating. We assumed that an increase in the degree of saturation of the surface of aminosilica with hydrogen ions leads to a change in the total surface concentration of silanol groups $C_{\equiv \mathrm{SiOHs}}$, involved in process (2). In this case, the constancy of the constants of protonation of amino groups and acid dissociation of silanol groups is postulated.

To reveal the type of dependence of the total concentration of silanol groups on the degree of titration of the surface from Eq. (7) with Eqs. (8) and (9) sub-
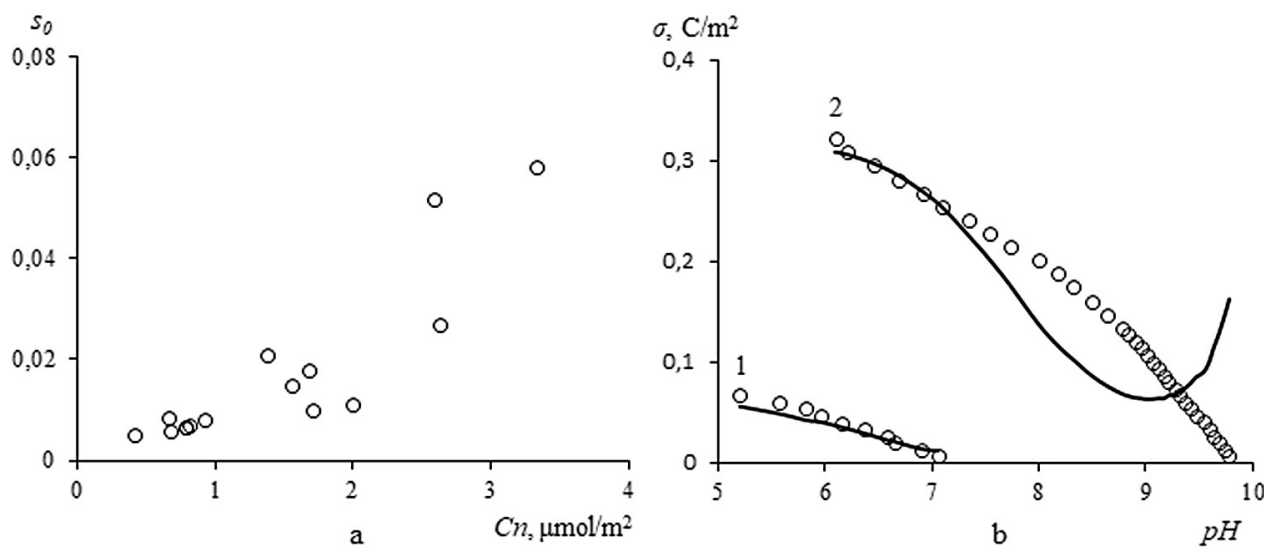

Fig. 1. Dependence of $s_{0}$ values on the surface concentration of amino groups (a); examples of approximation of experimental points by Eq. (7) (b):

1 - sample with $C_{-\mathrm{NH}_{2} \mathrm{~s}}=0.67 \mu \mathrm{mol} / \mathrm{m}^{2}, 2$ - sample with $C_{-\mathrm{NH}_{2} \mathrm{~s}}=3.33 \mu \mathrm{mol} / \mathrm{m}^{2}$ 
stituted there, we expressed $C_{\equiv \mathrm{SiOHs}}$. We used different values of $\log K$ in the vicinity of the propylamine protonation constant in solution: $\log K=9,10$ or 11 . Substituting the experimental values $\left[\mathrm{H}^{+}\right]$into the resulting equation, the desired dependence was obtained. Examples of the obtained dependences are shown in Fig. 2.

For all samples in the range of total hydrogen ion concentrations used by us, the dependences have a linear form. Based on this, $C_{\equiv \mathrm{SiOHs}}$ in Eq. (7) can be expressed as

$$
C_{\equiv \mathrm{SiOHs}}=a+b x,
$$

where $x$ is a parameter associated with the course of the titration process (titrant volume, total concentration of hydrogen ions), $a$ and $b$ are parameters selected for the numerical minimization of Eq. (7). The approximation results are shown in Fig. 3.

The curves in Fig. 3 indicate in favor of the fact that the model used by us satisfactorily describes the protonation of aminopropyl silicas with allowance for the effect of silanol groups on the surface. The mean value of the logarithm of the protonation constant is 10.55 , which is close to the thermodynamic constant of protonation of propylamine in an aqueous solution $(\log K=10.5$ [17]). Comparison of the $a$ constant with the concentration of amino groups on the surface indicates that $a$ is equal to the concentration of grafted amino groups. Thus, the interaction of amino groups with silanol groups in a 1:1 ratio is confirmed within the framework of this model. The average value of the $b$ constant is -0.0014 . Most likely, its value corresponds to the rate of decrease in the equilibrium concentration of amino groups with an increase in the degree of titration.

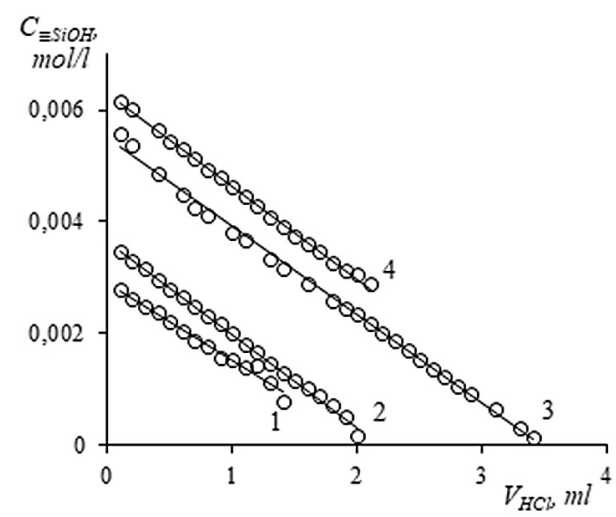

Fig. 2. Examples of obtained $C_{\equiv \mathrm{SiOHs}}=f\left(V_{\mathrm{HCl}}\right)$ dependences

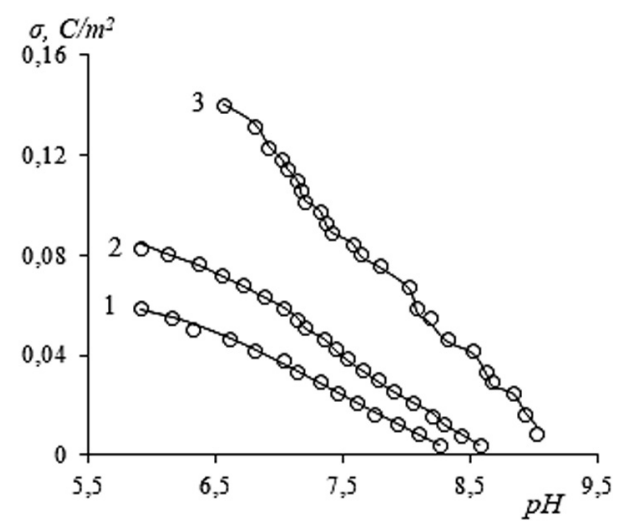

Fig. 3. Approximations of surface charge points calculated from experimental data by calculated lines:

$$
\begin{aligned}
& 1-C_{-\mathrm{NH}_{2} \mathrm{~s}}=0.65 \mu \mathrm{mol} / \mathrm{m}^{2}, \\
& 2-C_{-\mathrm{NH}_{2} \mathrm{~s}}=0.90 \mu \mathrm{mol} / \mathrm{m}^{2}, \\
& 3-C_{-\mathrm{NH}_{2} \mathrm{~s}}=1.51 \mu \mathrm{mol} / \mathrm{m}^{2}
\end{aligned}
$$

From the point of view of equilibria in solutions, the thesis of a decrease in the total concentration of one of the participants in the process does not stand up to criticism. However, on the surface of a solid, the groups are localized at specific points on the surface. The transformation of an amino group into an ammonium one leads to the disappearance of its interaction with silanol ones. Accordingly, the assumption of a decrease in the total number of silanol groups par- 
ticipating in equilibrium with an increase in the number of protonated amino groups seems logical. A change in the concentration of silanol groups during the process is equivalent to a different effect of silanol groups on amino groups that are unevenly distributed over the surface.

The model described in the work allows one to carry out a preliminary cal- culation of the isotherms of the sorption of hydrogen ions on aminosilica. For this, the ionization constant of propylamine in an aqueous solution and the concentration of aminopropyl on the surface are used. The only empirical parameter is the $b$ constant.

\section{Conclusions}

Our proposed model for describing protolytic equilibria is based on the following theses:

1. The process of protonation of amino silica is described using models of complexation on the surface, taking into account the effect of the electric double layer.

2. Silanol surface groups are direct parAmino groups on the surface are capable of deprotonating silanol groups. To take into account the influence of silanol groups, the equations of charge balances and material balance are used.

3. The total concentration of silanol groups involved in the process decreases during the process.

\section{References}

1. Davis GA, Kent DB. Surface complexation models in aqueous geochemistry. Rev. Mineral. Geochem. 1990;23(1):177-260.

2. Davis JA, James RO, Leckie JO. Surface ionization and complexation at the oxide / water interface. I. Computation of electrical double layer properties in simple electrolytes. J. Colloid Interface Sci. 1978;63(3):480-99. doi:10.1016/S0021-9797(78)80009-5

3. Kropacheva TN, Didik MV, Kornev VI. Modelirovaniye sorbtsii kationov tyazhelykh metallov gidroksidami v prisutstvii EDTA [Modeling of the heavy metal cations sorption by hydroxides in the EDTA presence]. Sorbtsionnyye i khromatograficheskiye protsessy. 2013;13(3):360-68. Russian.

4. Demianenko EM, Vlasova NN, Golovkova LP, Grebenyuk AG, Kuts VS, Lobanov VV. Izucheniye adsorbtsii akridina i proflavina na poverkhnosti kremnezema [Study of Acridine and Proflavine Adsorption on Silica Surface]. Khimiya, fizika i tekhnologiya poverkhnosti. 2012;3(2):142-54. Russian.

5. Moira KR, Machesky ML, Kubicki JD. Anatase Nanoparticle Surface Reactivity in NaCl Media: A CD-MUSIC Model Interpretation of Combined Experimental and Density Functional Theory Studies. Langmuir. 2013;29(27):8572-83. doi:10.1021/la4011955

6. Kholin YuV. Kolichestvennyy fiziko-khimicheskiy analiz kompleksoobrazovaniya $\mathrm{v}$ rastvorakh i na poverkhnosti khimicheski modifitsirovannykh kremnezemov: soderzhatel'nyye modeli, matematicheskiye metody. Khar'kov: Folio; 2000. 290 p. Russian. 
7. Khristenko IV, Kholin YuV. The greement of the results of quantitative physicalchemical analysis and probing surfaces of aminosilicas by Reichardt's solvatochromic betaine indicators. Kharkov University Bulletin. 2007;13(38):245-50.

8. Kobylinskaya NG, Zaytsev VN. Izucheniye protoliticheskikh svoystv kremnezemov, modifitsirovannykh 8-aminometilkhinolinom [Study of the modified with 8-aminomethylquinoline silicas protolytic properties]. Trudy Odesskogo politekhnicheskogo universiteta. 2006;1(25):231-6. Russian.

9. Barkauskas J, Dervinyte M. An investigation of the functional groups on the surface of activated carbons. J. Serb. Chem. Soc. 2004;69(5):363-75.

doi:10.2298/JSC0405363B

10. Chen L. C., Peng P. Y., Lin L. F., Yang T. C., Huang C. M. Facile preparation of nitrogen-doped activated carbon for carbon dioxide adsorption Aerosol Air Qual. Res. 2014;14(3):916-27. doi:10.4209/aaqr.2013.03.0089

11. Zaytsev VN. Funktsionalizirovannyye materialy. Tom 1. Kompleksoobrazuyushchiye kremnezemy: sintez, stroyeniye privitogo sloya i khimiya poverkhnosti. Seriya monogr. pod red. akad. V. V. Skopenko [Functionalized materials. Volume 1. Complexing silicas: synthesis, graft structure and surface chemistry. Monogr. ed. acad. V.V. Skopenko]. Khar'kov: Folio; 1997. 240 p. Russian.

12. Zhu M, Lerum MZ, Chen W. How to prepare reproducible, homogeneous, and hydrolytically stable aminosilane-derived layers on silica. Langmuir. 2012;28(1):416-23. doi:10.1021/la203638g

13. Bol'bukh YuN. Vysokodispersnyye kremnezemy s binarnymi aminometil'nymi i kremniygidrometil'nymi modifitsiruyushchimi sloyami [Highly dispersed silicas with the binary aminomethyl and silicon-hydromethyl modifying layers]. Nanostrukturnoye materialovedeniye. 2011;(2):44-61. Russian.

14. Sharov AV, Morozova TV, Kovyatkin YaV, Filisteev OV. Kolichestvennoye opisaniye vliyaniya silanol'nogo pokrova na kislotno-osnovnyye svoystva 3-aminopropilsilikageley [Quantitative description of silanol cover influence on the 3-aminopropyl silica acid-base properties]. Sorbtsionnyye i khromatograficheskiye protsessy. 2015;15(2):243-50. Russian.

15. Koopal LK, Yang Y, Minnaard AJ, Theunissen PLM, van Riemsdijk WH. Chemical immobilization of humic acid on silica. Colloids Surf. A. 1998;141(3):385-95. doi:10.1016/S0927-7757(97)00170-2

16. Vlasova NN. Sravneniye modeley kompleksoobrazovaniya na poverkhnosti dlya kolichestvennogo opisaniya kislotnykh svoystv vysokodispersnogo kremnezema [A comparison of surface complexation models for quantitative description of acidic properties of fumed silica]. Khimiya, fizika i tekhnologiya poverkhnosti. 2008;14:615. Russian.

17. Nikolsky BP, editor. Spravochnik khimika [Chemist's handbook]. Vol 3. Leningrad (USSR): Khimiya; 1965. 1008 p. Russian. 